University of Nebraska - Lincoln

DigitalCommons@University of Nebraska - Lincoln

\title{
Rapid detection of Shigella and enteroinvasive Escherichia coli in produce enrichments by a conventional multiplex PCR assay
}

\author{
Rachel Binet \\ U.S. Food and Drug Administration, rachel.binet@fda.hhs.gov \\ Deanne M. Deer \\ U.S. Food and Drug Administration \\ Samantha J. Uhlfelder \\ Oak Ridge Research Institute for Science and Education
}

Follow this and additional works at: https://digitalcommons.unl.edu/publichealthresources

Binet, Rachel; Deer, Deanne M.; and Uhlfelder, Samantha J., "Rapid detection of Shigella and enteroinvasive Escherichia coli in produce enrichments by a conventional multiplex PCR assay" (2014). Public Health Resources. 290.

https://digitalcommons.unl.edu/publichealthresources/290

This Article is brought to you for free and open access by the Public Health Resources at DigitalCommons@University of Nebraska - Lincoln. It has been accepted for inclusion in Public Health Resources by an authorized administrator of DigitalCommons@University of Nebraska - Lincoln. 


\title{
Rapid detection of Shigella and enteroinvasive Escherichia coli in produce enrichments by a conventional multiplex PCR assay
}

\author{
Rachel Binet $^{\mathrm{a}, *}$, Deanne M. Deer ${ }^{\mathrm{a}}$, Samantha J. Uhlfelder ${ }^{\mathrm{b}}$ \\ ${ }^{a}$ Division of Microbiology, Center for Food Safety and Applied Nutrition, U.S. Food and Drug Administration, College Park, MD 20740, USA \\ ${ }^{\mathrm{b}}$ Oak Ridge Research Institute for Science and Education, PO Box 117, Oak Ridge, TN 37830, USA
}

\section{A R T I C L E I N F O}

\section{Article history:}

Received 3 September 2013

Received in revised form

3 December 2013

Accepted 10 December 2013

Available online 19 December 2013

\section{Keywords:}

Rapid detection

Shigella

Enteroinvasive Escherichia coli

Multiplex PCR

Fresh produce

DNA extraction

\begin{abstract}
A B S T R A C T
Faster detection of contaminated foods can prevent adulterated foods from being consumed and minimize the risk of an outbreak of foodborne illness. A sensitive molecular detection method is especially important for Shigella because ingestion of as few as 10 of these bacterial pathogens can cause disease. The objectives of this study were to compare the ability of four DNA extraction methods to detect Shigella in six types of produce, post-enrichment, and to evaluate a new and rapid conventional multiplex assay that targets the Shigella ipaH, virB and mxiC virulence genes. This assay can detect less than two Shigella cells in pure culture, even when the pathogen is mixed with background microflora, and it can also differentiate natural Shigella strains from a control strain and eliminate false positive results due to accidental laboratory contamination. The four DNA extraction methods (boiling, PrepMan Ultra [Applied Biosystems], InstaGene Matrix [Bio-Rad], DNeasy Tissue kit [Qiagen]) detected $1.6 \times 10^{3}$ Shigella CFU/ml post-enrichment, requiring $\sim 18$ doublings to one cell in $25 \mathrm{~g}$ of produce pre-enrichment. Lower sensitivity was obtained, depending on produce type and extraction method. The InstaGene Matrix was the most consistent and sensitive and the multiplex assay accurately detected Shigella in less than 90 min, outperforming, to the best of our knowledge, molecular assays currently in place for this pathogen.
\end{abstract}

Published by Elsevier Ltd.

\section{Introduction}

Shigella species are important causes of diarrheal disease throughout the world and are probably the most common cause of bacterial dysentery. Transmission is mainly by direct contact with infected individuals through the fecal-oral route, although outbreaks may occasionally be associated with the consumption of contaminated food or water. Because ingestion of as few as 10-100 Shigella cells has been shown to cause disease in volunteers (Dupont et al., 1989), Shigella infections are recognized as a major public health threat and are therefore reportable. There are an estimated 164.7 million people worldwide infected by Shigella annually, resulting in 1.1 million deaths, mostly in children under 5 years. CDC surveillance programs for the years 2005-2008 reported 14,864 laboratory cases of shigellosis in the United States per year, of which nearly a third were foodborne related (Scallan et al., 2011). Nevertheless, most Shigella infections are not

\footnotetext{
* Corresponding author. Tel.: +1 240402 2468; fax: +1 3014362915.

E-mail address: rachel.binet@fda.hhs.gov (R. Binet).
}

reported or diagnosed and as many as 495,000 may occur each year in the United States alone.

The U.S. Food and Drug Administration (FDA) is responsible for monitoring the microbiological quality of all domestic and imported food sold in interstate commerce with the exception of poultry, meat and some egg products. Shigella species have distinctive biochemical and serological features that allow them to be easily identified by standard microbiologic techniques; but these techniques can take seven to ten days to produce results and are often not successful if the organism is in a stressed physiological state and/or outnumbered by native microbial flora (Binet and Lampel, 2013). The FDA Bacteriological Analytical Manual (BAM) method suggests enriching the pathogen in a low carbohydrate medium (Shigella broth) and incubating it in an anaerobic atmosphere at an elevated temperature in the presence of the antibiotic novobiocin (Mehlman et al., 1985; FDA, 2001). High-throughput monitoring of Shigella contamination in fresh produce is usually performed in standard incubators to avoid the use of anaerobic jars (Warren et al., 2009); but since bacteria achieve higher population densities under aerobic conditions, this method may result in Shigella being under-represented among indigenous microflora and missed on post-enrichment isolation plates. 
To improve the sensitivity of detection, various methods based on the genetic rather than phenotypic attributes of Shigella have been developed (Levin, 2009). Polymerase chain reaction (PCR) assays to diagnose Shigella rely mainly on the amplification of DNA fragments from the 220-kbp invasive plasmid shared by Shigella and certain serotypes of Escherichia coli, known as enteroinvasive E. coli (EIEC). This virulence plasmid can be spontaneously lost during growth outside the host, so popular PCR protocols use primers directed against the invasion plasmid antigen $i p a H$, which is present in multiple copies in Shigella and EIEC bacterial genomes (Sethabutr et al., 1993).

Current FDA procedures to detect Shigella in produce employ two successive conventional PCR assays (the first PCR assay is followed by a nested PCR assay for confirmation) that take several hours from beginning to end (Lindqvist, 1999; Warren et al., 2009). A strain of Shigella flexneri harboring an insertion in the mxiC virulence gene is used as a PCR control strain (Deer and Lampel, 2010).

In this study, we developed a rapid, reliable, sensitive and inexpensive single test tube multiplex PCR assay for the simultaneous detection of multicopy ipaH and single-copy mxiC and $v i r B$ virulence genes. The assay can detect Shigella or EIEC cells in the indigenous microflora of different types of produce, postenrichment. Because the boiling procedure currently recommended to prepare tested DNAs may not efficiently remove matrix-associated PCR inhibitors, we also evaluated three commercial DNA extraction kits by determining the lowest number of Shigella cells they could identify in the enrichment broth against the bacterial background microflora from the surface of tomatoes, sweet peppers, cilantro, parsley, cucumbers and green onions.

\section{Materials and methods}

\subsection{Bacterial strains and culturing methods}

Three hundred and twenty six bacterial isolates were used to determine the specificity of the assay. These strains (Table 1) included 232 Shigella isolates from clinical and food sources and one control strain, S. flexneri $2457 \mathrm{M}$, a genetically modified version of wild-type $S$. flexneri 2457T harboring a cassette conferring kanamycin resistance into the mxiC gene (Deer and Lampel, 2010). Ninety-four non-Shigella species were also tested, including several known to be genetically close to Shigella such as E. coli (59 strains, including 49 EIEC isolates) and Salmonella enterica (24 strains). The strains were grown overnight in Tryptic Soy Broth (TSB) at $30{ }^{\circ} \mathrm{C}$ to increase the probability that the Shigella strains maintained the invasion plasmid (Schuch and Maurelli, 1997).

\subsection{Nucleic acid isolation}

Bacterial genomic DNA extraction was routinely performed using the DNeasy Blood and Tissue Kit (Qiagen, Germantown, MD) procedure (Binet and Maurelli, 2009), eluting in $100 \mu \mathrm{l} \mathrm{TE}$ buffer, in about 15-20 min. Three additional DNA extraction methods were chosen for their simplicity and potential application for highthroughput analyses (preferably one tube, one buffer, and few manipulation steps). The five-minute boiling method in $500 \mu \mathrm{l}$ PBS currently used in the FDA import and domestic produce methodologies for Shigella (Warren et al., 2009) was compared to two commercial, heat-based methods. For the PrepMan Ultra (Applied Biosystems, Foster City, CA), the sample pellet was resuspended in $100 \mu \mathrm{l}$ of PrepMan solution and heated at $100{ }^{\circ} \mathrm{C}$ for $10 \mathrm{~min}$. For the InstaGene Matrix (Bio-Rad, Hercules, CA.), the sample pellet
Table 1

Specificity of the multiplex PCR assay using the Qiagen fast-cycling PCR master mix.

\begin{tabular}{|c|c|c|c|c|}
\hline \multirow[t]{2}{*}{ Species } & \multirow[t]{2}{*}{ No. of isolates tested } & \multicolumn{3}{|c|}{ Percentage positive } \\
\hline & & ipaH & mxiC & $\operatorname{vir} B$ \\
\hline Shigella sonnei & 57 & 100 & 26 & 26 \\
\hline S. dysenteriae & 54 & 100 & 65 & $63^{\mathrm{a}}$ \\
\hline S. boydii & 38 & 100 & 68 & 68 \\
\hline S. flexneri & 81 & 100 & 62 & 62 \\
\hline S. flexneri BS103 ${ }^{\mathrm{b}}$ & 1 & 100 & 0 & 0 \\
\hline S. flexneri $2457 \mathrm{M}^{\mathrm{c}}$ & 1 & 100 & 0 & 100 \\
\hline $\begin{array}{l}\text { Enteroinvasive } \\
\quad \text { Escherichia coli }\end{array}$ & 49 & 100 & 80 & $76^{\mathrm{a}}$ \\
\hline Enteroaggregative $E$. coli & 1 & 0 & 0 & 0 \\
\hline Enterohemorrhagic $E$. coli & 5 & 0 & 0 & 0 \\
\hline Enteropathogenic E. coli & 1 & 0 & 0 & 0 \\
\hline Enterotoxigenic E. coli & 1 & 0 & 0 & 0 \\
\hline E. coli $\mathrm{K} 12$ & 2 & 0 & 0 & 0 \\
\hline Aeromonas hydrophila & 1 & 0 & 0 & 0 \\
\hline Citrobacter freundii & 1 & 0 & 0 & 0 \\
\hline Edwardsiella tarda & 1 & 0 & 0 & 0 \\
\hline Enterobacter cloacae & 1 & 0 & 0 & 0 \\
\hline Hafnia alvei & 1 & 0 & 0 & 0 \\
\hline Klebsiella pneumoniae & 1 & 0 & 0 & 0 \\
\hline Morganella morganii & 1 & 0 & 0 & 0 \\
\hline Proteus vulgaris & 1 & 0 & 0 & 0 \\
\hline Pseudomonas aeruginosa & 1 & 0 & 0 & 0 \\
\hline Salmonella enterica & 24 & 0 & 0 & 0 \\
\hline Serratia marcescens & 1 & 0 & 0 & 0 \\
\hline Yersinia enterocolitica & 1 & 0 & 0 & 0 \\
\hline
\end{tabular}

a One isolate showed amplicons for both $\mathrm{ipaH}$ and mxiC but none for virB.

b $S$. flexneri control strain that does not have the virulence plasmid.

c $S$. flexneri control strain that contains an insertion in mxiC.

was resuspended in $200 \mu \mathrm{l}$ of the commercial chelex-based solution and heated at $56{ }^{\circ} \mathrm{C}$ for $20 \mathrm{~min}$ and then at $100{ }^{\circ} \mathrm{C}$ for $10 \mathrm{~min}$. In these three methods, the DNA was cooled then centrifuged for $1 \mathrm{~min}$ at $16,000 \times \mathrm{g}$ to eliminate cell debris. The PrepMan Ultra samples were also diluted 1:10 in sterile water, as recommended by the manufacturer, to help reduce potential inhibitory effects in the PCR.

\subsection{Primer design}

Primers targeting the ipaH, mxiC and virB genes of Shigella and EIEC were designed using Clone Manager 9 (Scientific \& Educational Software, Durham, NC), based on the virulence plasmid and genome sequences of Shigella and EIEC available at GenBank (Accession Nos. CP001064, NC_010660, NC_004851, NC_007607, NC_007385, AL391753, AF348706, NC_007608, NC_004851 and AY879342 for the virulence plasmid sequences and NZ_AAKB02000001, NC_010658, NC_007613, NC_007606, AE005674, NC_008258, AE014073 and NC_007384 for the complete genome sequences). RB87 (5'CGGTCAGCCACCCTCTGAG-3') and RB88 (5'-CTTGACCGCCTTTCCGATACC- $3^{\prime}$ ) target the multicopy ipaH gene, yielding a 613 bp amplification product. RB89 (5'-AAGTTCTGACGCGATTGG-3') and RB90 (5'TGTACGCGATCAAGAATCCC- $3^{\prime}$ ) target the virB virulence gene located on the virulence plasmid, yielding a $415 \mathrm{bp}$ amplification product. RB110 (5'-CGAGCTGTAATGCTTATGAGT-3') and RB111 (5'-TCATGACTGGCTCGTGATAC-3') target the mxiC virulence gene located on the virulence plasmid, creating a $232 \mathrm{bp}$ amplification product in wildtype Shigella strains or a $1050 \mathrm{bp}$ amplicon in the $2457 \mathrm{M}$ control strain. All primers were manufactured by Integrated DNA Technologies, Inc. (Coralville, IA), resuspended in sterile water to a $100 \mathrm{pmol} / \mu \mathrm{l}$ concentration each, and stored at $-20^{\circ} \mathrm{C}$. A primer working mix containing $100 \mu \mathrm{lBB} 87+100 \mu \mathrm{l} \mathrm{RB88}+400 \mu \mathrm{l} \mathrm{RB} 89+400 \mu \mathrm{l} \mathrm{RB90}+400 \mu \mathrm{l}$ $\mathrm{RB} 110+400 \mu \mathrm{lRB} 111$ was combined, aliquoted into smaller volumes to limit successive freeze/thaw cycles, and stored at $-20^{\circ} \mathrm{C}$. 


\subsection{PCR assays}

PCR conditions are summarized in Table 2. PCR amplifications were conducted in a $20 \mu \mathrm{l}$ reaction containing $2 \mu \mathrm{l}$ of DNA sample, $1.8 \mu \mathrm{l}$ of the primer working mix (10 pmol RB87 and RB88 primers and 40 pmol RB89, RB90, RB110 and RB111 primers), $10 \mu \mathrm{l} 2 \times$ fastcycling PCR master mix (Qiagen) and $2 \mu \mathrm{l} 10 \times$ Qiagen CoralLoad dye. Amplification conditions were $5 \mathrm{~min}$ at $95^{\circ} \mathrm{C}, 30$ cycles of $5 \mathrm{~s}$ at $96{ }^{\circ} \mathrm{C}, 10 \mathrm{~s}$ at $57^{\circ} \mathrm{C}, 20 \mathrm{~s}$ at $68^{\circ} \mathrm{C}$, and a final extension of $1 \mathrm{~min}$ at $72{ }^{\circ} \mathrm{C}$, resulting in about an hour run on the DNA engine Tetrad from MJ Research (Bio-Rad). As recommended by the PCR enzyme manufacturer, PCR amplifications were also attempted on the fastcycling Eppendorf Mastercycler ep gradient $S$ thermal cycler (Eppendorf AG, Hamburg, Germany) using $98{ }^{\circ} \mathrm{C}$ as the denaturation temperature for three-step cycling, resulting in a 32-44 min run, depending on annealing and extension conditions. When PCR amplification was performed using regular HotStarTaq Plus DNA polymerase (Qiagen) or the Qiagen Multiplex PCR kit, amplification was 5 or $15 \mathrm{~min}$ at $95^{\circ} \mathrm{C}$, respectively, followed by 30 cycles of $30 \mathrm{~s}$ at $94^{\circ} \mathrm{C}, 30 \mathrm{~s}$ or $90 \mathrm{~s}$ at $57^{\circ} \mathrm{C}$, respectively, $45 \mathrm{~s}$ at $72{ }^{\circ} \mathrm{C}$, and a final extension of $1 \mathrm{~min}$ at $72{ }^{\circ} \mathrm{C}$. PCR amplifications in the DNA engine Tetrad from MJ Research lasted $1 \mathrm{~h} 40$ min with the HotStarTaq Plus Master Mix kit and 2 h 15 min with the Qiagen Multiplex kit.

\subsection{Sample analysis and scoring}

After PCR amplification, $10 \mu \mathrm{l}$ of each reaction mixture was loaded onto a $2 \%$ agarose gel containing $0.8 \mu \mathrm{g} / \mathrm{ml}$ ethidium bromide and separated in $0.5 \times$ TAE buffer ( $40 \mathrm{nM}$ Tris-acetate, $\mathrm{pH} 8.0$ and $1 \mathrm{mM} \mathrm{Na}{ }_{2}$ EDTA) for 40 min using the RunOne ${ }^{\mathrm{TM}}$ Electrophoresis System (Embi Tec, San Diego, CA) at 100 V. PCR amplicons were visualized with UV light and band sizes were calculated by comparison to molecular size markers (O'Generuler $1 \mathrm{~kb}$ DNA Ladder and O'Generuler 100 bp DNA Ladder; Thermo Scientific Molecular Biology, Waltham, MA). Each PCR was performed at least three times with replicate samples. All replicates behaved similarly. Consequently, for clarity, only one replicate was shown in the figures, when appropriate.

\subsection{Sensitivity of the multiplex PCR assay}

To determine the sensitivity of the multiplex PCR assay, $1 \mathrm{ml}$ of exponential phase cultures containing $1.4 \times 10^{8} \mathrm{CFU}$ and $9.5 \times 10^{7} \mathrm{CFU}$ for S. flexneri $2457 \mathrm{~T}$ and $2457 \mathrm{M}$, was used to extract DNA by the 5-min boiling method. Aliquots of genomic DNA were frozen for storage and serially diluted 10 -fold with sterile water at the time of the experiment. DNA templates of each bacterium representing $10^{5}, 10^{4}, 10^{3}, 10^{2}, 10$ and 1 colony forming-unit (CFU) were subjected to the multiplex PCR.

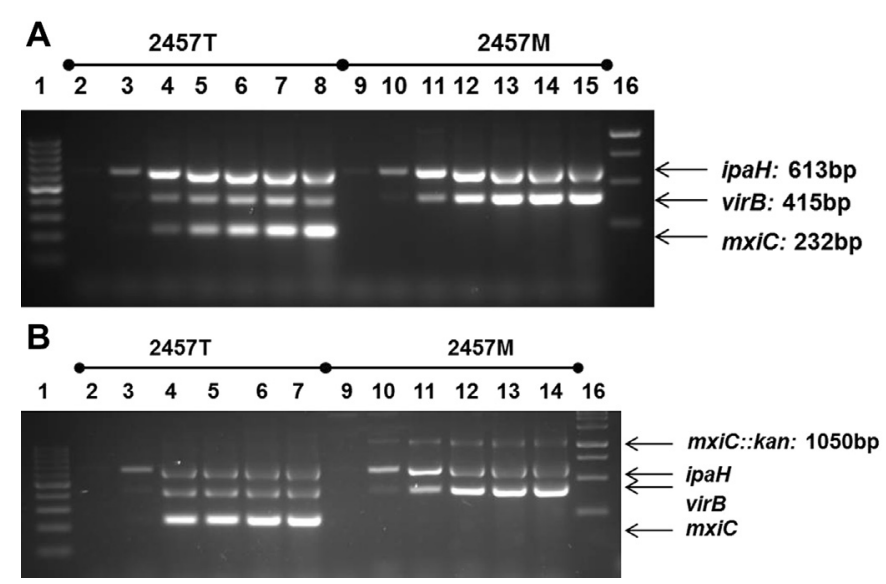

Fig. 1. Multiplex PCR reaction on serial dilutions of Shigella flexneri wild-type (2457T: lanes 2-8) and mxiC::kan mutant (2457M: lanes 9-15) using the Qiagen Fast cycling PCR mix (A) and the Qiagen Multiplex PCR kit (B). $10 \mu \mathrm{l}$ of PCR products were loaded on a $2 \%$ agarose, $2(16+2)$ lanes, EMBI TEC pre-cast gel, and run at $100 \mathrm{~V}$ for $1 \mathrm{~h} 1: 3 \mu \mathrm{l}$ O'Generuler 100 pb DNA ladder (Fisher Scientific, Pittsburgh, PA). 2/9: 0.6/0.4 CFU equivalent. 3/10: 5.6/3.8 CFU equivalent. 4/11: 56/38 CFU equivalent. 5/12: (5.6/ 3.8) $\times 10^{2} \mathrm{CFU}$ equivalent. 6/13: $(5.6 / 3.8) \times 10^{3} \mathrm{CFU}$ equivalent. 7/14: $(5.6 /$ 3.8) $\times 10^{4}$ CFU equivalent. 8/15: (5.6/3.8) $\times 10^{5}$ CFU equivalent. 16: $3 \mu$ l O'Generuler $1 \mathrm{~kb}$ DNA ladder (Fisher Scientific, Pittsburg, PA).

\subsection{Effect of indigenous microflora on PCR detection of Shigella in produce}

Total bacterial counts on the produce samples (cilantro, sweet pepper, tomato, parsley, green onion and cucumber) were performed on Tryptic Soy Agar (TSA) plates after enrichment in Shigella broth [2\% Tryptone, $0.2 \% \mathrm{~K}_{2} \mathrm{HPO}_{4}, 0.2 \% \mathrm{KH}_{2} \mathrm{PO}_{4}, 0.5 \% \mathrm{NaCl}, 0.1 \%$ Glucose, $0.15 \%$ Tween 80 ] containing $0.5 \mu \mathrm{g} / \mathrm{ml}$ novobiocin (Warren et al., 2009). One tomato, one sweet pepper, one cucumber, a bunch of cilantro, a bunch of parsley and a bunch of green onions were purchased from a local grocery store in the Washington, D.C. area, weighed and placed in a sterile bag. Sterile PBS was added to each bag at a ratio of $4.5 \mathrm{ml}$ to $1 \mathrm{~g}$ of produce. After 5 min of gentle mixing or massaging, $50 \mathrm{ml}$ of each rinsate was transferred to a $500 \mathrm{ml}$ Erlenmeyer flask containing $50 \mathrm{ml}$ of $2 \times$ Shigella broth supplemented with $1 \mu \mathrm{g} / \mathrm{ml}$ novobiocin, mixed, and then incubated at $37{ }^{\circ} \mathrm{C}$ for $20 \mathrm{~h}$. For the green onion sample, a soak method was used instead of the rinse. A volume of $2 \times$ Shigella broth containing $1 \mu \mathrm{g} / \mathrm{ml}$ novobiocin equivalent to the volume of PBS in the sample was added directly to the bag containing the material and incubated at $37^{\circ} \mathrm{C}$ for $20 \mathrm{~h}$. One ml of each post-enrichment culture was aliquoted into microcentrifuge tubes, pelleted and stored at $-40^{\circ} \mathrm{C}$.

S. flexneri cells used as inoculum were taken from a $30{ }^{\circ} \mathrm{C}$ exponential phase culture diluted in phosphate buffered saline (PBS) to reach $2.6 \pm 0.5 \times 10^{7}$ bacteria per ml. Six microliters of the

Table 2

PCR conditions.

\begin{tabular}{|c|c|c|c|c|}
\hline Qiagen PCR kit & PCR platform & Amplification condition & Run time & Reference to agarose gel \\
\hline Multiplex PCR & DNA Engine Tetrad & $95^{\circ} \mathrm{C} 15 \mathrm{~min} ;\left[94{ }^{\circ} \mathrm{C} 30 \mathrm{~s}, 57{ }^{\circ} \mathrm{C} 90 \mathrm{~s}, 72{ }^{\circ} \mathrm{C} 45 \mathrm{~s}\right] \times 30$; followed by $72{ }^{\circ} \mathrm{C} 1 \mathrm{~min}$ & $2 \mathrm{~h} 15 \mathrm{~min}$ & Fig. 1B \\
\hline $\begin{array}{l}\text { HotStarTaq Plus } \\
\text { Master Mix }\end{array}$ & DNA Engine Tetrad & $95^{\circ} \mathrm{C} 5 \mathrm{~min} ;\left[94^{\circ} \mathrm{C} 30 \mathrm{~s}, 57^{\circ} \mathrm{C} 30 \mathrm{~s}, 72{ }^{\circ} \mathrm{C} 45 \mathrm{~s}\right] \times 30$; followed by $72{ }^{\circ} \mathrm{C} 1 \mathrm{~min}$ & $1 \mathrm{~h} 40 \mathrm{~min}$ & Fig. 3A; Fig. 4 \\
\hline \multirow[t]{6}{*}{ Fast-cycling PCR } & DNA engine Tetrad & $95^{\circ} \mathrm{C} 5 \mathrm{~min} ;\left[96{ }^{\circ} \mathrm{C} 5 \mathrm{~s}, 57^{\circ} \mathrm{C} 10 \mathrm{~s}, 68^{\circ} \mathrm{C} 20 \mathrm{~s}\right.$ ] $\times 30$; followed by $72{ }^{\circ} \mathrm{C} 1 \mathrm{~min}$ & $1 \mathrm{~h}$ & $\begin{array}{l}\text { Fig. 1A; Fig. 2; Fig. 3B; } \\
\text { Fig 4F2 }\end{array}$ \\
\hline & & $95{ }^{\circ} \mathrm{C} 5 \mathrm{~min} ;\left[96{ }^{\circ} \mathrm{C} 5 \mathrm{~s}, 57^{\circ} \mathrm{C} 10 \mathrm{~s}, 68{ }^{\circ} \mathrm{C} 20 \mathrm{~s}\right] \times 25$; followed by $72{ }^{\circ} \mathrm{C} 1 \mathrm{~min}$ & $52 \mathrm{~min}$ & Fig. 3G \\
\hline & Mastercycler ep & $95{ }^{\circ} \mathrm{C} 5 \mathrm{~min} ;\left[98^{\circ} \mathrm{C} 5 \mathrm{~s}, 57{ }^{\circ} \mathrm{C} 10 \mathrm{~s}, 68{ }^{\circ} \mathrm{C} 45 \mathrm{~s}\right] \times 30$; followed by $72{ }^{\circ} \mathrm{C} 1 \mathrm{~min}$ & $44 \mathrm{~min}$ & Fig. 3C; Fig. 5 \\
\hline & Gradient S & $95{ }^{\circ} \mathrm{C} 5 \mathrm{~min} ;\left[98^{\circ} \mathrm{C} 5 \mathrm{~s}, 57^{\circ} \mathrm{C} 10 \mathrm{~s}, 68^{\circ} \mathrm{C} 30 \mathrm{~s}\right] \times 30$; followed by $72{ }^{\circ} \mathrm{C} 1 \mathrm{~min}$ & $36 \min$ & Fig. 3D \\
\hline & & $95{ }^{\circ} \mathrm{C} 5 \mathrm{~min} ;\left[98{ }^{\circ} \mathrm{C} 5 \mathrm{~s}, 55^{\circ} \mathrm{C} 10 \mathrm{~s}, 68{ }^{\circ} \mathrm{C} 20 \mathrm{~s}\right] \times 30$; followed by $72{ }^{\circ} \mathrm{C} 1 \mathrm{~min}$ & $36 \mathrm{~min}$ & Fig. 3E \\
\hline & & $95{ }^{\circ} \mathrm{C} 5 \mathrm{~min} ;\left[98^{\circ} \mathrm{C} 5 \mathrm{~s}, 57{ }^{\circ} \mathrm{C} 10 \mathrm{~s}, 68{ }^{\circ} \mathrm{C} 20 \mathrm{~s}\right] \times 30$; followed by $72{ }^{\circ} \mathrm{C} 1 \mathrm{~min}$ & $32 \mathrm{~min}$ & Fig. 3F \\
\hline
\end{tabular}


suspension undiluted, diluted 10 -fold and 100 -fold (corresponding to $1.6 \pm 0.3 \times 10^{5}, 1.6 \pm 0.3 \times 10^{4}$, and $1.6 \pm 0.3 \times 10^{3}$ bacteria, respectively) were added to the frozen pellets, in triplicate, and then transferred back to the freezer until DNA isolation.

\section{Results}

\subsection{Optimization of the multiplex PCR assay}

Initially, each primer set (RB87 and RB88 for ipaH, RB89 and RB90 for virB, and RB110 and RB111 for $m x i C$ ) was tested separately to ensure that they gave a single product corresponding to the predicted molecular size for each amplicon (data not shown). Genome analysis of the 15 Shigella and EIEC genome and virulence plasmid sequences available in public databases showed that the RB87 and RB88 ipaH primers can recognize the five to seven copies and the four to five copies of ipaH located on the chromosome and the invasion plasmid, respectively, depending on the bacterial isolate. The multiplex assay was therefore designed to contain four times more primers directed against the $\operatorname{virB}$ and mxiC single-copy genes than primers directed against the multicopy ipaH gene. The assay was still sensitive enough to detect less than 10 Shigella cells in pure culture (Fig. 1A) in $1 \mathrm{~h}$ and $40 \mathrm{~min}$ from start to finish (a onehour PCR reaction using the fast-cycling PCR kit on the DNA Tetrad thermocycler followed by a 40-min agarose gel electrophoresis on the RunOne system). The wild-type $S$. flexneri strain showed three bands at the predicted molecular size while the mutant $2457 \mathrm{M}$ showed only 2 bands for ipaH and virB, whether the HotStar Taq Plus enzyme was used with the Master Mix kit (data not shown) or with the fast cycling PCR kit (Fig. 1A; Table 1). A band at $\sim 1 \mathrm{~kb}$ corresponding to the mxiC::kan amplicon was seen only with 2457M when the multiplex reactions were performed with the Qiagen Multiplex PCR mix (Fig. 1B).

\subsection{Specificity of the multiplex PCR assay}

The specificity of the multiplex PCR assay was tested against a total of 232 Shigella strains (83 S. flexneri, 57 Shigella sonnei, 54 Shigella dysenteriae, 38 Shigella boydii) and 94 non-Shigella strains belonging to 13 other genera including 49 EIECs (Table 1). The results showed that DNA templates from all Shigella and EIECs yielded a 600 bp amplicon (ipaH product) (Fig. 2). Most samples that maintained the virulence plasmid generated the three expected amplification products. One $S$. dysenteriae isolate and one EIEC isolate showed only amplification products for ipaH and mxiC (data not shown). Except for EIEC, no amplification was detected using the ipaH, mxiC and virB primer sets on other non-Shigella isolates (Table 1).

\subsection{Efficiency of the multiplex PCR assay under ultra-fast cycling conditions}

The Eppendorf mastercycler ep gradient $\mathrm{S}$ thermal cycler runs a standard PCR in about 30 min due to its extremely fast cooling and
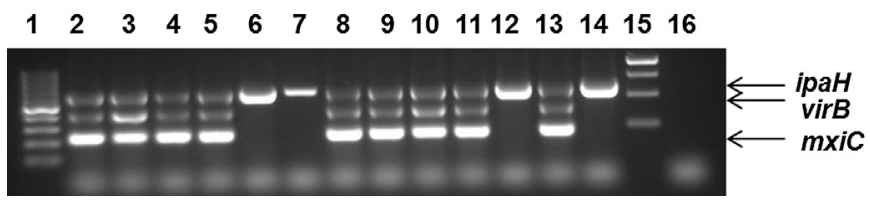

Fig. 2. Multiplex PCR reactions on various Shigella and enteroinvasive E. coli (EIEC) isolates using the Qiagen Fast cycling PCR mix. $10 \mu \mathrm{l}$ of PCR products were loaded on a $2 \%$ agarose, $2(16+2)$ lanes, EMBI TEC pre-cast gel, and run at $100 \mathrm{~V}$ for $40 \mathrm{~min} 1: 3 \mu \mathrm{l}$ O'Generuler 100 pb DNA ladder. 2-4: S. flexneri. 5-6: S. sonnei. 7-9: S. boydii. 10-12: S. dysenteriae 13-14: EIEC. 15: $3 \mu \mathrm{l}$ O'Generuler $1 \mathrm{~kb}$ DNA ladder. 16: negative control. heating rates. Using conditions optimized for this thermocycler per the manufacturer's recommendations (Fig. 3, condition F), the multiplex assay lasted $32 \mathrm{~min}$ and underperformed. Various annealing and extension conditions were attempted to obtain runs lasting from 32 to $44 \mathrm{~min}$. Amplification for ipaH remained relatively strong in all conditions for isolates lacking the virulence plasmid (Fig. 3, lanes 1); but for isolates that carried the virulence plasmid, amplification, for virB particularly, became less efficient as the runs shortened (Fig. 3, lane 2). Instead of increasing the annealing time or lowering the annealing temperature (Fig. 3, condition E), a lengthening of the extension steps from 20 to $45 \mathrm{~s}$ (Fig. 3, condition C, a 44-min run) was utilized to help compensate for the diminished reaction efficiency. The multiplex assay still performed well in the DNA engine Tetrad thermocycler using 25 amplification cycles (Fig. 3, condition G, a 52-min run).

\subsection{Effect of indigenous microflora and sample preparation on PCR detection of Shigella in produce}

Typically, enrichment protocols for Shigella in food involve growing produce rinsates in Shigella broth in the presence of $0.5-$ $3 \mu \mathrm{g} / \mathrm{ml}$ of novobiocin at $38-44{ }^{\circ} \mathrm{C}$ for about $20 \mathrm{~h}$ (FDA, 2001; Mehlman et al., 1985; Warren et al., 2009; International Organization for Standardization, 2004). To lower the variability between samples, the indigenous flora from various produce types was first enriched overnight in Shigella broth containing $0.5 \mu \mathrm{g} / \mathrm{ml}$ of novobiocin and titered on non-selective TSA plates, yielding from $0.5 \times 10^{9} \mathrm{CFU} / \mathrm{ml}$ in parsley to $1.6 \times 10^{10} \mathrm{CFU} / \mathrm{ml}$ in green onions (with bulbs, leaves and some roots). For the other four produce types tested, post-enrichment bacterial counts were from 1.4 to $2.6 \times 10^{9} \mathrm{CFU} / \mathrm{ml}$. One $\mathrm{ml}$ of each enrichment culture was then spiked with various 10 -fold dilutions of a pure Shigella culture (Table 3), prior to DNA isolation.

Four DNA extraction methods were compared based on their DNA recovery efficiency and the suitability of the recovered DNA for PCR amplification. With a capacity limit of $2 \times 10^{9}$ cells, the Qiagen DNeasy columns could not handle the green onion samples due to the high bacterial load obtained post-enrichment. As per manufacturers' recommendation, DNA samples were collected in different volumes depending on the method used for DNA isolation, $500 \mu \mathrm{l}$ for the boiling method, $200 \mu \mathrm{l}$ for InstaGene and $100 \mu \mathrm{l}$ for the DNeasy and the PrepMan Ultra methods. Consequently, for a same spiking dose, the ratio of Shigella DNA to competitor DNA differed in each sample (Table 3).

Fig. 4 shows the amplification results from the DNA engine tetrad using DNA prepared from $1 \mathrm{ml}$ enriched samples spiked with $1.6 \pm 0.3 \times 10^{2}$ to $1.6 \pm 0.3 \times 10^{5}$ wild-type $S$. flexneri cells. Although most DNA samples contained Shigella DNA, we noticed differences

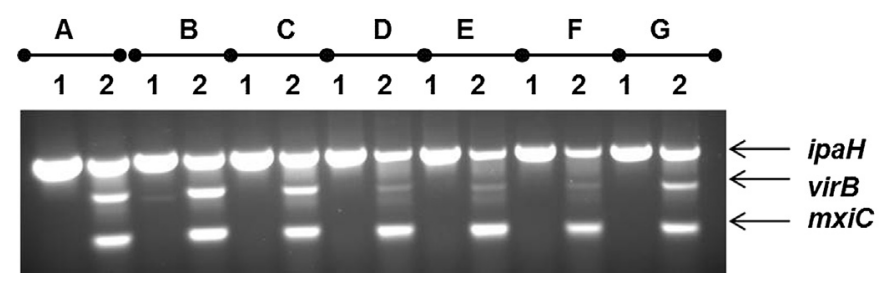

Fig. 3. Impact of assay duration on efficiency of the multiplex PCR on a Shigella isolate lacking (1) or harboring (2) the virulence plasmid. PCR was performed on the DNA engine Tetrad thermocycler using regular HotStarTaq Plus DNA polymerase (A; lasting $1 \mathrm{~h} 40 \mathrm{~min}$ ), or the fast-cycling PCR master mix using 30 cycles (B; $1 \mathrm{~h}$ ) or 25 cycles (G; $52 \mathrm{~min})$. PCR with the fast-cycling mix was also accomplished on the Eppendorf Mastercycler ep gradient $S$ thermal cycler as recommended by the manufacturer $(\mathrm{F}$; $32 \mathrm{~min}$ ) or with modifications such as extension for $45 \mathrm{~s}$ (C; $44 \mathrm{~min}$ ) or $30 \mathrm{~s}$ (D; $36 \mathrm{~min})$, instead of $20 \mathrm{~s}$, or annealing at $55^{\circ} \mathrm{C}(\mathrm{E} ; 36 \mathrm{~min})$ instead of $57^{\circ} \mathrm{C}$. 
Table 3

Bacterial counts representing S. flexneri organisms introduced post-enrichment.

\begin{tabular}{|c|c|c|c|c|c|}
\hline \multicolumn{2}{|c|}{$\begin{array}{l}\text { Post-enrichment } \\
\text { S. flexneri counts }\end{array}$} & \multicolumn{4}{|c|}{$\begin{array}{l}\text { CFU equivalent in DNAs used in } \\
\text { the PCR assays }{ }^{\text {b }}\end{array}$} \\
\hline $\mathrm{CFU} / \mathrm{ml}$ & $\mathrm{CFU} / \mathrm{g}$ produce & Boiling & InstaGene & DNeasy & $\begin{array}{l}\text { PrepMan } \\
\text { Ultra }^{c}\end{array}$ \\
\hline$[1.6 \pm 0.3]$ E5 & {$[1.4 \pm 0.3]$ E6 } & 320 & 800 & 1600 & 160 \\
\hline$[1.6 \pm 0.3] \mathrm{E} 4$ & {$[1.4 \pm 0.3]$ E5 } & 32 & 80 & 160 & 16 \\
\hline$[1.6 \pm 0.3]$ E3 & {$[1.4 \pm 0.3] \mathrm{E} 4$} & 3.2 & 8 & 16 & 1.6 \\
\hline$[1.6 \pm 0.3] \mathrm{E} 2$ & {$[1.4 \pm 0.3] \mathrm{E} 3$} & $0.3^{\mathrm{d}}$ & $0.8^{\mathrm{d}}$ & $1.6^{\mathrm{d}}$ & $0.2^{\mathrm{d}}$ \\
\hline
\end{tabular}

a Various dilutions of an exponential culture of $S$. flexneri $2457 \mathrm{~T}$ were added to $1 \mathrm{ml}$ of indigenous cells collected after overnight enrichment from various produce types.

b DNA samples have different volumes depending on the method used for DNA isolation, $500 \mu \mathrm{l}$ for the boiling method, $200 \mu \mathrm{l}$ for InstaGene and $100 \mu \mathrm{l}$ for the DNeasy and the PrepMan Ultra methods. $2 \mu \mathrm{l}$ was used in the multiplex assay.

c DNA samples were diluted 1:10 in the PCR assays.

d Prepared by diluting the DNA samples corresponding to the indigenous flora spiked with $[1.6 \pm 0.3] \times 10^{3}$ CFU of Shigella 1:10 using unspiked DNA samples.

depending on the produce types, the method used to prepare the DNA, and even the polymerase used in the multiplex reaction. Most InstaGene- and DNeasy-prepared DNA samples could be used undiluted, improving the sensitivity of the multiplex assay (Fig. 4; lanes 2 and 3, respectively). On the other hand, most DNA samples collected with the PrepMan Ultra method were strongly inhibitory to the multiplex PCR reaction and therefore needed to be diluted 1:10 with sterile water, as per the manufacturer's recommendations (Fig. 4.; lanes 4 and $4^{*}$ ). This was seen with the HotStarTaq

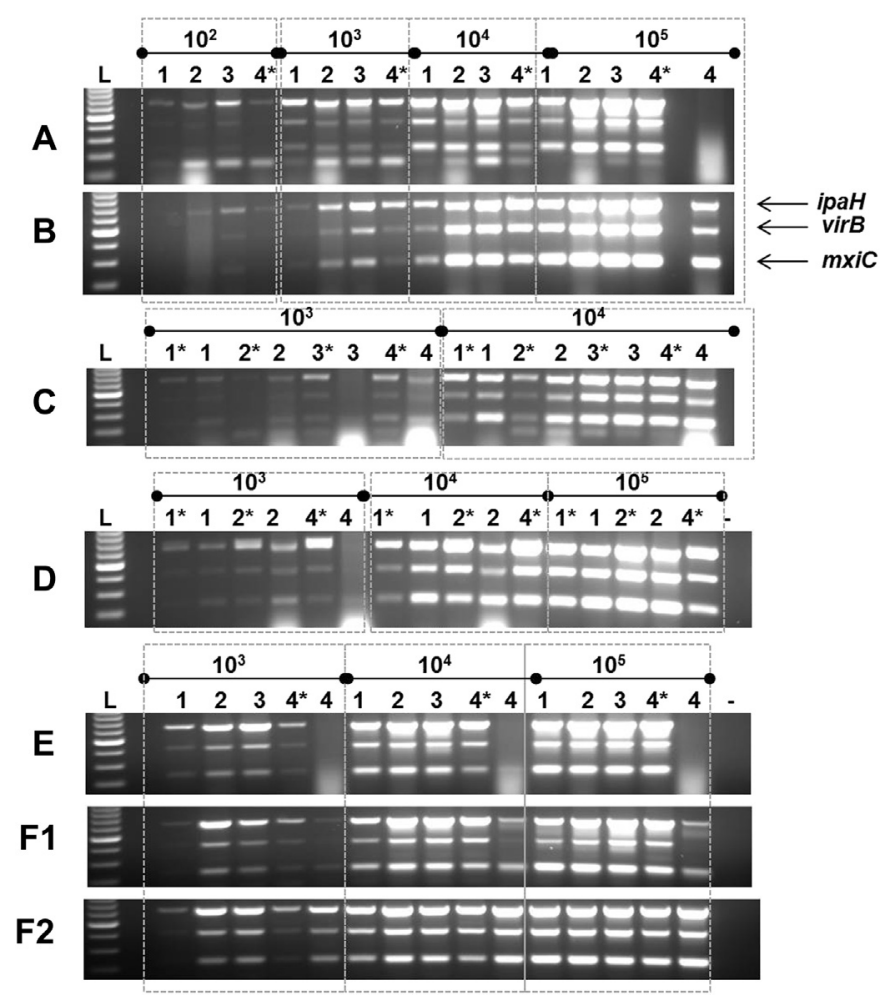

Fig. 4. Detection of various numbers of Shigella cells in six produce types, postenrichment. PCR was run on the DNA engine Tetrad using HotStarTaq Plus DNA polymerase (A-F1) or the fast-cycling PCR master mix (F2), using $2 \mu$ l DNA prepared with the boiling procedure (1), the Bio-Rad InstaGene matrix (2), Qiagen DNeasy kit (3) and the Applied Biosystems PrepMan Ultra reagent (4). DNA samples diluted 1:10 in the multiplex assay are marked with * A: Tomato. B: Parsley. C: Cilantro. D: Green onion. E: Cucumber. F: Sweet pepper. L: O'Generuler 100 pb DNA ladder. - : negative control.
Plus DNA polymerase (Fig. 4A-F1) and the fast-cycling PCR master mix although, for the sweet pepper DNA samples only, the fastcycling master mix relieved the inhibition observed with the undiluted PrepMan Ultra DNA samples (Fig. 4F1 and F2). For the other samples, we did not notice any differences in the amplification outcome using the HotStarTaq Plus DNA polymerase or the fastcycling PCR master mix on the DNA engine Tetrad (data not shown). PCR inhibition was also observed with both polymerases in the DNeasy cilantro DNA samples and the InstaGene green onion DNA samples (Fig. 4C and D).

All DNA samples prepared from produce samples spiked with at least $1.6 \pm 0.3 \times 10^{3}$ Shigella cells (containing between 2 and 16 Shigella cell-equivalent DNAs in the PCR reaction) showed consistent amplification of $i p a H, v i r B$ and mxiC gene products for all produce types (Fig. 4). The amplification products were less intense for the cilantro and green onion DNA samples compared to the other DNA samples, suggesting that PCR inhibitors were associated with these two produce types. Inhibition was also observed for the parsley DNA samples, but only when DNA was prepared with the boiling procedure. Nevertheless, Shigella was detected in all samples containing about $10^{3}$ cells of the pathogen per $\mathrm{ml}$ with the multiplex PCR assay with the $1 \mathrm{~h}$ fast-cycling PCR master mix amplification run or with the $1 \mathrm{~h} 40$ min HotStarTaq Plus DNA polymerase amplification run. This limit of detection will identify the presence of 1 Shigella cell per gram of produce if the cell undergoes 14 doublings during enrichment, and will detect the presence of one cell in $25 \mathrm{~g}$ of produce if the cell undergoes 18 doublings during enrichment (Table 4).

Samples spiked with 10 times less Shigella (requiring 10 or 15 doublings during enrichment whether one cell is present in $1 \mathrm{~g}$ or in $25 \mathrm{~g}$ of produce, respectively) (Table 4), showed the three expected amplification products in some samples only. The Shigella DNA was too diluted in the DNA samples prepared by boiling and showed amplification only for the multicopy virulence gene ipaH at best (Fig. 4).

When the DNA samples prepared from inoculated produce enrichments were tested with the Eppendorf mastercycler ep gradient $S$ thermal cycler 44-min amplification run, the sensitivity of detection remained in the $1.6 \pm 0.3 \times 10^{3}$ Shigella cells per ml range (data not shown), but the PCR efficiency (yield) appeared slightly lower, especially for virB (Fig. 5), as expected (Fig. 3).

\subsection{Effect of PCR additives on PCR detection of Shigella in produce}

Although our exclusivity panel failed to reveal any cross reactivity with the $i p a H, v i r B$ and $m x i C$ primer sets except for Shigella and EIEC isolates in pure cultures (Table 1 ), we observed an $\sim 150$ bp non-specific amplification product in the unspiked (data not shown) and spiked enriched tomato and cilantro DNA samples (Figs $4 \mathrm{~A}$ and $\mathrm{C}, 5$ ). For the tomato samples in particular, this undesired product appeared to compete with the specific amplification of ipaH and/or virB.

Because adding PCR-enhancing agents can increase the yield of the desired PCR product or decrease production of undesired products (Chakrabarti and Schutt, 2001; Henegariu et al., 1997; Binet and Maurelli, 2007; Kreader, 1996), we looked at whether using glycerol, Dimethyl sulfoxide (DMSO) or Bovine Serum Albumin (BSA) in the multiplex PCR assay instead of water would significantly improve the PCR efficiency or specificity (Fig. 5). While the addition of $10 \%$ glycerol improved PCR specificity, it also caused preferential amplification of ipaH over the other two targets. The addition of 5\% DMSO had no effect on the undesired product, and the addition of $0.8 \mu \mathrm{g} / \mathrm{ml}$ BSA had a positive effect on some samples and a negative effect on others (Fig. 5). The same trend was observed with the $1 \mathrm{~h}$ and $1 \mathrm{~h} 40 \mathrm{~min}$ amplification runs (data not 
Table 4

Shigella growth required during enrichment for detection.

\begin{tabular}{|c|c|c|c|c|c|c|c|}
\hline \multirow[t]{2}{*}{ Post-enrichment $S$. flexneri counts CFU/ml } & \multicolumn{4}{|c|}{ LOD using enrichment ratio $1: 9$} & \multicolumn{3}{|c|}{ LOD using of enrichment ratio $1: 4.5$} \\
\hline & $\mathrm{CFU} / \mathrm{g}$ produce & Doubling $^{\mathrm{a}}$ & $\mathrm{CFU} / 25 \mathrm{~g}$ produce & Doubling $^{\mathrm{a}}$ & $\mathrm{CFU} / \mathrm{g}$ produce & $\mathrm{CFU} / 25 \mathrm{~g}$ produce & Doubling $^{\mathrm{a}}$ \\
\hline$[1.6 \pm 0.3] \mathrm{E} 5$ & {$[1.4 \pm 0.3] \mathrm{E} 6$} & 20.1_20.7 & {$[3.5 \pm 0.7] \mathrm{E} 7$} & 24.7_25.3 & {$[7.2 \pm 1.3] \mathrm{E} 5$} & {$[1.8 \pm 0.3] \mathrm{E} 7$} & $23.8 \_24.3$ \\
\hline$[1.6 \pm 0.3] \mathrm{E} 4$ & {$[1.4 \pm 0.3] \mathrm{E} 5$} & $16.8 \_17.4$ & {$[3.5 \pm 0.7] \mathrm{E} 6$} & $21.4 \_22.0$ & {$[7.2 \pm 1.3] \mathrm{E} 4$} & {$[1.8 \pm 0.3] \mathrm{E} 6$} & 20.521 \\
\hline$[1.6 \pm 0.3] \mathrm{E} 3$ & {$[1.4 \pm 0.3] \mathrm{E} 4$} & $13.5 \_14.9$ & {$[3.5 \pm 0.7] \mathrm{E} 5$} & $18.1 \_18.7$ & {$[7.2 \pm 1.3] \mathrm{E} 3$} & {$[1.8 \pm 0.3] \mathrm{E} 5$} & $17.2 \_17.7$ \\
\hline$[1.6 \pm 0.3] \mathrm{E} 2$ & {$[1.4 \pm 0.3] \mathrm{E} 3$} & 10.1_10.8 & {$[3.5 \pm 0.7] \mathrm{E} 4$} & 14.7_15.4 & {$[7.2 \pm 1.3] \mathrm{E} 2$} & {$[1.8 \pm 0.3] \mathrm{E} 4$} & 13.9_14.4 \\
\hline
\end{tabular}

Shigella growth requirements associated to the low LODs of $1.6 \pm 0.3 \times 10^{3}$ cells per $\mathrm{ml}$ are highlighted in grey.

a The number of doublings associated with specific bacterial counts was calculated on http://www.consumptiongrowth101.com/DoublingPeriods.php.

shown); addition of DMSO, glycerol or BSA caused the preferential amplification of $i p a H$ but did not improve the sensitivity of the assay (data not shown).

\section{Discussion}

Time is of the essence when identifying and tracing contaminated commodities. Detecting contamination more quickly can prevent an adulterated food from being consumed and minimize the risk of an outbreak of foodborne illness (Hoorfar, 2011).

In this study, we evaluated the ability of a conventional multiplex PCR assay using a fast-cycling DNA polymerase to rapidly and specifically detect Shigella in produce. The assay took less than 90 min, including a 40-min electrophoresis step on the Embi-Tec RunOne system. Switching to the Invitrogen E-gel ${ }^{\circledR}$ electrophoresis system may even further shorten the assay by another $15 \mathrm{~min}$ (Insook Son, personal communication), resulting in Shigella detection in about $65 \mathrm{~min}$.

A common limitation of this Shigella multiplex assay is its inability to discriminate Shigella isolates from EIEC (Fig. 2). Although EIEC are much less prevalent in food than Shigella, they still cause dysentery and are therefore not allowed in commodities. EIEC and Shigella may share a high degree of sequence similarity, but they can still be biochemically differentiated because EIEC, unlike Shigella, is motile and is a lactose, mucate, and/or acetate fermenter (Binet and Lampel, 2013). In addition, these pathogens grow differently on Rainbow Agar Shigella/Aeromonas (Biolog, Hayward, CA). After an overnight incubation at $35{ }^{\circ} \mathrm{C}$, Shigella species produce mauve colonies while EIEC colonies are blue (Deer and Lampel, 2010).

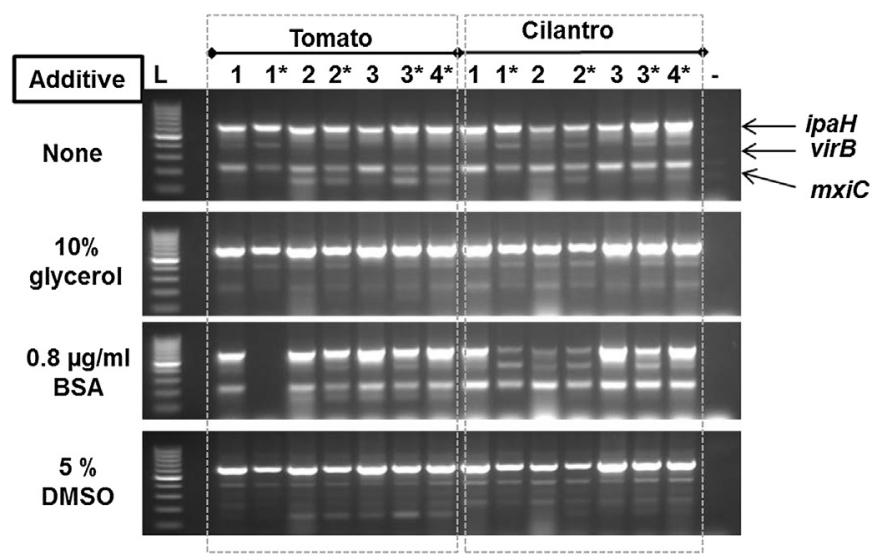

Fig. 5. Variation in the specificity and efficiency of the multiplex assay in presence of various PCR additives. PCR was run on the Eppendorf Mastercycler ep gradient $S$ thermal cycler using the 44-min fast-cycling assay in presence or absence of $10 \%$ glycerol, $0.8 \mu \mathrm{g} / \mathrm{ml} \mathrm{BSA}$ or $5 \%$ DMSO, using $1 \mu \mathrm{l}$ of DNA prepared from the $10^{5}$ Shigella spiked enrichment samples with the boiling procedure (1), the Bio-Rad InstaGene matrix (2), Qiagen DNeasy kit (3) and the Applied Biosystems PrepMan Ultra reagent (4). DNA samples diluted 1:10 in the multiplex assay are marked with *. L: O'Generuler 100 pb DNA ladder. - : negative control.
Most PCR assays for the detection of Shigella in food are based on the sole detection of ipaH and cannot differentiate between natural isolates or cross-contamination with the genetically engineered S. flexneri 2457M FDA positive control strain (Mokhtari et al., 2013; Garrido et al., 2013; Lin et al., 2010; Wang et al., 2007; Warren et al., 2006). Accidental in-laboratory sample contamination with $2457 \mathrm{M}$ could generate a false-positive result that could lead to regulatory action and/or the destruction of the tested food. The conventional multiplex assay in this study can differentiate natural Shigella isolates (harboring the virulence plasmid or plasmidless) from $2457 \mathrm{M}$ that carries a kanamycin resistance cassette into the virulence plasmid mxiC gene. $2457 \mathrm{M}$ showed only two bands - one for ipaH at $\sim 600$ bp and one for virB at $\sim 400 \mathrm{bp}-$ but failed to reveal any amplification product for mxiC::kan at 1050 bp due to the short (20 s) amplification step of the assay. Wild-type Shigella isolates contain three amplification products that are revealed at $613 \mathrm{bp}, 415 \mathrm{bp}$ and $232 \mathrm{bp}$; but because Shigella tends to lose its virulence plasmid upon storage and subculturing, only one band may appear at 613 bp (Thong et al., 2005). Targeting virB, therefore, ensured that plasmidless Shigella isolates were easily differentiated from 2457M in the multiplex assay. The addition of kanamycin to the culture of the 2457M control strain ensures that it maintains its virulence plasmid, thus virB. If a natural $\mathrm{mxiC}^{-}$virB ${ }^{+} \mathrm{ipaH}^{+}$Shigella isolate is recovered from food, it can still be differentiated from $2457 \mathrm{M}$ when the multiplex reactions are performed with the Qiagen Multiplex PCR mix (Fig. 1B); but for general use, the fast-cycling multiplex assay can identify Shigella more quickly than looking for the mxiC::kan marker using the Qiagen Multiplex PCR master mix. (44 min vs 2 h 15 min, respectively).

The efficiency of the multiplex assay was further confirmed when we looked for Shigella in artificially contaminated food samples. The sensitive detection of foodborne pathogens in produce requires optimal cell lysis and efficient DNA purification to remove associated PCR inhibitors (Schrader et al., 2012). Boiling in PBS or water has been the DNA isolation method of choice in the FDA Survey of Domestic and Import Fresh Produce assignments for Shigella because its cost is low and it can easily be used to process a large volume of samples, however there is no step to remove eventual food matrix-associated PCR inhibitors (Warren et al., 2009). Such inhibitors would cause false negative PCR results with potentially serious public health consequences when a contaminated food is not removed from circulation. We found that the reagents and methods used in DNA extraction had some impact on the PCR outcome. The presence of inhibitors produced false negative PCR results in DNA prepared from three commercial DNA extraction kits, but this effect was not seen with the boiling method, probably because the DNA and DNA inhibitors were more diluted. Indeed, we found that diluting the DNA template 1:10 before the assay reduced the concentration of inhibitory compounds to a level that did not affect DNA amplification and Shigella could be detected. Nevertheless, as a protective measure, it may be useful to add an internal amplification control as we did recently for 
the TaqMan-based multiplex real-time assay for Shigella and EIEC (Deer and Lampel, 2010).

The boiling method failed for the samples spiked with $10^{2}$ Shigella cells $/ \mathrm{ml}$. A higher level of sensitivity was obtained for DNAs prepared with the three commercial DNA extraction kits, but because of the capacity limit of the DNeasy columns and PrepMan Ultra reagent PCR inhibition, the InstaGene matrix appeared more suited to process produce samples after enrichment. The low limit of detection (LOD) of the multiplex assay for Shigella in produce is higher than the LOD in real-time PCR (Deer and Lampel, 2010; Lin et al., 2010); but in these two studies, the LOD was estimated from spiked rinses from various produce types rather than from spiked post-enrichment medium resulting in fewer competitive microflora.

Most molecular assays nowadays use real-time PCR technology that combines PCR chemistry with a fluorescent probe detection of the amplified product in the same vessel. However, if a qualitative yes or no answer is required, this technology is too complicated and expensive (Kuchta et al., 2005). When multiple targets are recorded, data processing can be time consuming. While traditional, conventional endpoint PCR assays are simpler in design, they do require a post-PCR processing step in the form of agarose-gel electrophoresis to determine the molecular weight of the amplified product(s). Interestingly, numerous PCR kits contain a gel loading dye so the transfer from the PCR tube to the gel requires no additional step, minimizing opening of tubes after amplification. In addition, multichannel pipette-compatible agarose gels or combs are now being offered by several manufacturers, making them ideal for most high-throughput, endpoint PCR applications. The high level of sensitivity of PCR creates its own drawbacks, as low-level laboratory carryover contamination by previously amplified nucleic acids can generate false positive results. Precautionary measures should be taken to limit the risk, such as meticulous processing, introducing negative controls, and extracting and amplifying the DNA in different rooms when possible or using a PCR workstation and changing gloves regularly (Kwok and Higuchi, 1989; Maurer, 2011).

While the use of TaqMan probes generally improves the specificity of real-time PCR assays, the non-specific amplification product seen with our multiplex assay in the cilantro and tomato samples could not been mistaken as one of the pre-determined target of interest due to its much smaller size.

While it is clear that this multiplex assay could expedite the analysis of food for Shigella contamination, success is linked to the ability of the pathogen to compete with resident microflora. Food legislation in many countries requires the absence of Shigella in $25 \mathrm{~g}$ sample sizes. Since it is not possible to directly carry out PCR on $25 \mathrm{~g}$ of produce, an enrichment step is necessary. The current FDA bacteriological analytical method for Shigella recommends a $1: 9$ ratio of grams of produce to mls of enrichment media, meaning that $25 \mathrm{~g}$ of commodities are tested in $225 \mathrm{ml}$ of enrichment medium and $1 \mathrm{~g}$ of food is tested in $9 \mathrm{ml}$ of enrichment medium. Because the LOD of the multiplex assay lies between $1.6 \times 10^{2}$ and $1.6 \times 10^{3} \mathrm{CFU}$ per ml, 9 times more cells (between 1400 and 14,000) and 9*25 times more Shigella cells (between $3.5 \times 10^{4}$ and $3.5 \times 10^{5}$ ) need to arise during enrichment from $1 \mathrm{~g}$ and $25 \mathrm{~g}$ of produce, respectively (Table 4). Consequently, if one Shigella cell is present in $25 \mathrm{~g}$ of produce pre-enrichment, the multiplex assay will show presence of the pathogen if that cell underwent 18.45 doublings during enrichment (Table 4). If the ratio of produce $(\mathrm{g})$ to enrichment media $(\mathrm{mL})$ was $1: 4.5$, the doubling requirement will not vary much (Table 4 ). More information is needed on the growth of Shigella during enrichment to evaluate the risk, if any, of using molecular assays to support the food legislation for Shigella.

\section{Acknowledgments}

We thank Vikas Gill (FDA, College Park, MD) for his assistance in procuring the produce samples and Barbara Berman (FDA, College Park, MD) for proofreading the manuscript.

\section{References}

Binet, R., Lampel, K.A., 2013. Shigella species. In: Doyle, M.P., Buchanan, R.L. (Eds.), Food Microbiology: Fundamentals and Frontiers. ASM Press, Washington DC, pp. 377-399.

Binet, R., Maurelli, A.T., 2007. Frequency of development and associated physiological cost of azithromycin resistance in Chlamydia psittaci 6BC and C. trachomatis L2. Antimicrob. Agents Chemother. 51, 4267-4275.

Binet, R., Maurelli, A.T., 2009. Transformation and isolation of allelic exchange mutants of Chlamydia psittaci using recombinant DNA introduced by electroporation. Proc. Natl. Acad. Sci. U. S. A. 106, 292-297.

Chakrabarti, R., Schutt, C.E., 2001. The enhancement of PCR amplification by low molecular-weight sulfones. Gene 274, 293-298.

Deer, D.M., Lampel, K.A., 2010. Development of a multiplex real-time PCR assay with internal amplification control for the detection of Shigella species and enteroinvasive Escherichia coli. J. Food Prot. 73, 1618-1625.

Dupont, H.L., Levine, M.M., Hornick, R.B., Formal, S.B., 1989. Inoculum size in shigellosis and implications for expected mode of transmission. J. Infect. Dis. 159, 1126-1128.

FDA, 2001. Shigella. In: Bacteriological Analytical Manual Online. http://www.fda. gov/Food/FoodScienceResearch/LaboratoryMethods/ucm070789.htm (Last accessed 22.07.13.).

Garrido, A., Hapela, M., Oman, B., Erreira, M., Ago, J., Ieites, J., Abado, A., 2013. Development of a multiplex real-time PCR method for simultaneous detection of Salmonella enterica, Shigella flexneri and Listeria monocytogenes in processed food samples. Eur. Food Res. Technol. 234, 571-580.

Henegariu, O., Heerema, N.A., Dlouhy, S.R., Vance, G.H., Vogt, P.H., 1997. Multiplex PCR: critical parameters and step-by-step protocol. BioTechniques 23, 504-511.

Hoorfar, J., 2011. Rapid detection, characterization, and enumeration of foodborne pathogens. APMIS Suppl., 1-24.

International Organization for Standardization, 2004. Microbiology of Food and Animal Feeding Stuffs - Horizontal Method for the Detection of Shigella spp.

Kreader, C.A., 1996. Relief of amplification inhibition in PCR with bovine serum albumin or T4 gene 32 protein. Appl. Environ. Microbiol. 62, 1102-1106.

Kuchta, T., Kaclikova, E., Oravcova, K., 2005. Contained detection of food-borne pathogenic bacteria by 5 '-nuclease polymerase chain reaction and end-point fluorometry. In: Riley, A.P. (Ed.), Food Policy, Control and Research. Nova Science Publishers, Inc. pp. 111-123.

Kwok, S., Higuchi, R., 1989. Avoiding false positives with PCR. Nature 339, 237-238.

Levin, R.E., 2009. Molecular methods for detecting and discriminating Shigella associated with foods and human clinical infections a review. Food Biotechnol. 23, 214-228.

Lin, W.S., Cheng, C.M., Van, K.T., 2010. A quantitative PCR assay for rapid detection of Shigella species in fresh produce. J. Food Prot. 73, 221-233.

Lindqvist, R., 1999. Detection of Shigella spp. in food with a nested PCR methodsensitivity and performance compared with a conventional culture method. J. Appl. Microbiol. 86, 971-978.

Maurer, J.J., 2011. Rapid detection and limitations of molecular techniques. Annu. Rev. Food Sci. Technol. 2, 259-279.

Mehlman, I.J., Romero, A., Wentz, B.A., 1985. Improved enrichment for recovery of Shigella sonnei from foods. J. Assoc. Off. Anal. Chem. 68, 552-555.

Mokhtari, W., Nsaibia, S., Gharbi, A., Aouni, M., 2013. Real-time PCR using SYBR Green for the detection of Shigella spp. in food and stool samples. Mol. Cell. Probes 27, 53-59.

Scallan, E., Hoekstra, R.M., Angulo, F.J., Tauxe, R.V., Widdowson, M.A., Roy, S.L., et al., 2011. Foodborne illness acquired in the United States-major pathogens. Emerg. Infect. Dis. 17, 7-15.

Schrader, C., Schielke, A., Ellerbroek, L., Johne, R., 2012. PCR inhibitors - occurrence, properties and removal. J. Appl. Microbiol. 113, 1014-1026.

Schuch, R., Maurelli, A.T., 1997. Virulence plasmid instability in Shigella flexneri 2a is induced by virulence gene expression. Infect. Immun. 65, 3686-3692.

Sethabutr, O., Venkatesan, M., Murphy, G.S., Eampokalap, B., Hoge, C.W., Echeverria, P., 1993. Detection of Shigellae and enteroinvasive Escherichia coli by amplification of the invasion plasmid antigen H DNA sequence in patients with dysentery. J. Infect. Dis. 167, 458-461.

Thong, K.L., Hoe, S.L., Puthucheary, S.D., Yasin, R., 2005. Detection of virulence genes in Malaysian Shigella species by multiplex PCR assay. BMC Infect. Dis. 5, 8.

Wang, L., Li, Y., Mustaphai, A., 2007. Rapid and simultaneous quantitation of Escherichia coli 0157:H7, Salmonella, and Shigella in ground beef by multiplex real-time PCR and immunomagnetic separation. J. Food Prot. 70, 1366-1372.

Warren, B.R., Lampel, K.A., Schneider, K.R., 2009. Shigella. In: Liu, D. (Ed.), Molecular Detection of Foodborne Pathogens. CRC Press, Boca Raton, Florida, pp. 471-484

Warren, B.R., Yuk, H.G., Schneider, K.R., 2006. Detection of Shigella sonnei in selected foods by flow-through immunocapture followed by real-time polymerase chain reaction or isolation on MacConkey agar. J. Rapid Methods Autom. Microbiol. 14 309-324. 